\title{
$\mathrm{CO1}$
}

\section{A Comparison of Four Fields in the Ghanaian Late Cretaceous Wedge Play}

R. Mecklenburgh* (Tullow Oil plc)

\section{SUMMARY}

Between 2007 and 2013 Tullow Oil and its partners have proven four commercially viable light oil and condensate fields. The first, already producing since 2010, was the world class Jubilee field. The partnership has recently secured permission to develop the TEN area comprising the Tweneboa, Enyenra and Ntomme fields. 


\section{Introduction}

Between 2007 and 2013 Tullow Oil and its partners have proven four commercially viable light oil and condensate fields. The first, already producing since 2010, was the world class Jubilee field. The partnership has recently secured permission to develop the TEN area comprising the Tweneboa, Enyenra and Ntomme fields. The Tano basin contains a thick upper Cretaceous wedge of marine, clastic sequences sourced from a hinterland to the north via a concealed paleo-input. These sediments, over-lying earlier Cretaceous oil prone source rocks, appear to have been channelled by pre-existing offshore structures. All four fields are believed to have some element of stratigraphic trapping combined with some key fault bounded components, particularly in the Jubilee field. The depth of burial and quality of the reservoirs provide optimal conditions for AVO analysis that allows a clear delineation of the sand prone geometries within each field. This clear delineation shows varying sand distribution patterns from narrow channels to broad fans. The development plans have been optimised to suit these differing geometries, combining gas injection with both down flank and pattern water flood techniques. 